\section{Consumer perception of generic drug packages and its influence on product choice: a study in Minas Gerais, Brazil}

\section{Percepção dos consumidores sobre embalagens de medicamentos genéricos e sua influência na escolha do produto: um estudo no interior de Minas Gerais}

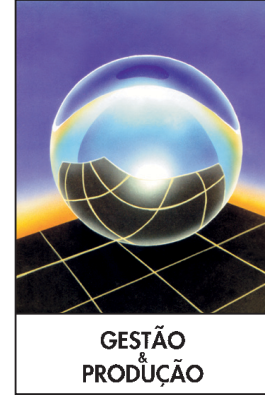

ISSN 0104-530X (Print) ISSN 1806-9649 (Online)

\author{
João Marcos Barbosa Carneiro' \\ Estela Maria Pérez Díaz ${ }^{2}$ \\ Eduardo Romeiro Filho ${ }^{1}$
}

\begin{abstract}
How to cite: Carneiro, J. M. B., Díaz, E. M. P., \& Romeiro Filho, E. (2019). Consumer perception of generic drug packages and its influence on product choice: a study in Minas Gerais, Brazil. Gestão \& Produção, 26(1), e2157. https://doi.org/10.1590/0104-530X2157-19
\end{abstract}

\begin{abstract}
The variety of generic drugs available has been remarkable in the Brazilian pharmaceutical sector, which allows the consumer wide freedom of choice among the various presentations for the same agent. Recognized as equivalent in quality and effectiveness, these presentations differ only in external aspects of the formulation, such as brand, price, advertisement, packaging, etc. In this context, knowing the determinants that lead to a specific choice is very important since it can provide adequate positioning according to the real consumer perception, resulting in a competitive differential. Thus, the focus of this study is perception, understanding and possible impact generated by the packaging and label of generic drugs in a small city located in Minas Gerais state, Brazil. The main objective of this article is to raise aspects related to the packaging of generic drugs considered by consumers as elements of choice and preference. For the study, two focus groups and direct observations were made with consumers of generic drugs, to acquire impressions from several labels of the same drug, followed by the formulation and application of a questionnaire. The questionnaire was divided into four blocks, with (1) personal information; (2) general aspects of drugs understanding; (3) packaging perception; and (4) scenario evaluation. Finally, the treatment and analysis of the data obtained as the basis for the conclusions of the study is presented.
\end{abstract}

Keywords: Product development; Packing; Consumer behavior; Generic drugs.

Resumo: A variedade de rótulos genéricos disponíveis tem sido marcante no setor farmacêutico nacional o que possibilita ao consumidor ampla liberdade de escolha dentre as várias apresentações existentes para um mesmo medicamento. Reconhecidas como equivalentes em qualidade e eficácia, essas apresentações diferem entre si apenas em pontos externos a formulação, como marca, preço, propaganda, embalagem etc. Nesse contexto, conhecer os determinantes que levam a uma escolha especifica tem particular importancia na medida em que pode proporcionar um adequado posicionamento frente aos reais desejos dos clientes, resultando em um diferencial competitivo. Assim, o enfoque desse estudo são percepções, entendimentos e possíveis impactos gerados pela embalagem de medicamentos genéricos em uma pequena cidade do interior de Minas Gerais. O objetivo central deste artigo é levantar aspectos ligados à embalagem de medicamentos genéricos considerados pelos consumidores como elementos de escolha e preferência. Para o estudo foram realizados dois grupos focais e observações diretas junto aos consumidores de medicamentos genéricos, para captação de impressões a partir de várias apresentações de um mesmo medicamento,

\footnotetext{
${ }^{1}$ Laboratório Integrado de Design e Engenharia de Produção - LIDEP, Departamento de Engenharia de Produção, Universidade Federal de Minas Gerais - UFMG, Av. Antônio Carlos, 6627, Pampulha, CEP 31270-901, Belo Horizonte, MG, Brasil, e-mail: jmarcosbc@hotmail.com; romeiro@ufmg.br

${ }^{2}$ Instituto Federal de Minas Gerais - IFMG, Av. Serra da Piedade, 299, Morada da Serra, CEP 34515-640, Sabará, MG, Brasil, e-mail: estela.maria@ifmg.edu.br

Received Mar. 30, 2017 - Accepted Feb. 27, 2018

Financial support: FAPEMIG - Fundação de Amparo à Pesquisa do Estado de Minas Gerais (Research Support Fundation of Minas Gerais State) and CNPq - Conselho Nacional de Desenvolvimento Científico e Tecnológico (National Counsel of Technological and Scientific Development).
} 
seguido da formulação e aplicação de um questionário em uma cidade de Minas Gerais. O questionário formulado foi dividido em quatro blocos, com informações pessoais; aspectos gerais sobre os medicamentos; percepção da embalagem e Avaliação de cenários. Por fim, é apresentado o tratamento e análise dos dados obtidos que serviram de base para as conclusões do estudo.

Palavras-chave: Desenvolvimento do produto; Embalagem; Comportamento do consumidor; Medicamento genérico.

\section{Introduction}

The development and production of drugs in Brazil went through several stages, from the creation of small national companies to the progressive denationalization of the Brazilian market and the progressive entry of multinational pharmaceutical companies from the 1960s (Evans, 1982). The Brazilian pharmaceutical industry is characterized by low investment in research and development, which leads to a small number of patents and a "[...] low degree of incentive to domestic producers to engage in international property rights" (Nishijima et al., 2014, p. 166). Since the adoption of Law No. 9,787 (February 10, 1999) titled "Generics Law" (Brasil, 1999), the Brazilian pharmaceutical sector has been surrounded by a new and highly competitive scenario, in which the profound re-laying of the foundations of the sector has brought a new reality, marked, among other points, by the advent of several labels for the same drug. Generic drugs represent a watershed for the drug industry and pharmaceutical laboratories, taking them out of the "comfort zone" (Santos \& Pinho, 2012). Analyzing from the perspective of the consumer, it became possible to choose between either reference or generic drug, as well as between the various generic representations and labels available. Despite this situation experienced after 1999, it is observed that economically more affordable alternatives already existed for certain drugs, called "similar drugs".

The crucial point linked to the Generics Law is related to the establishment of strict guarantees regarding the effectiveness of the new drug, which has led to the gradual clarification of the population as to what these drugs and their quality standards. In addition, factors such as the significant reduction in price, when compared to the reference drug, and the large percentage of profit from this segment help to boost sales. Thus, the growth of the participation of generics, both in market share and in the revenues of companies in the industry, whether manufacturers, distributors or retailers, is highly evident.

The Brazilian regulation of generic drugs allowed the consumer to choose among several available representations, including the existing "similar drugs". Factors such as price reductions help boost their sales and growth of generic market share, while aspects such as advertising are also relevant for the diffusion of brands and products linked to the drug industry (Heineck et al., 1998). Carvalho et al. (2006) define "price", "quality" and "equivalence" as important aspects for the generic drugs consumer. These aspects are related to the consumer's perception of the medicine and may involve various factors such as experiences, culture, desires and knowledge.

In this sense, it is worth highlighting the packaging as a relevant element, since its characteristics are quickly incorporated to the consumer perception and also contribute to the formulation of a general concept about the product (Miranda \& Romeiro, 2008). In this way, understanding the actual perception of the consumer about generic drugs from their packaging is important to establish some of the criteria that lead to the acceptance or not of a particular drug. Another highlight is the differentiation promoted by the package. In a scenario where for a given drug there are several products that are distinguished only in points such as packaging, label, brand and price, to analyze these issues in depth and to determine the field and degree of influence of each item can be key to an adequate positioning against the real needs and desires of consumers. Understanding the actual consumer's perception about generic drugs, the environment in which they are inserted and the particular characteristics of each product. Becomes fundamental for the design of marketing policies and product development (in this case packaging) aimed at the formation of a robust, consistent image that meets the expectations of customers and that can become a competitive differential for drug companies.

In this way, the objective of this work is to evaluate to understanding and perception of users and non-users regarding generic drugs from their packaging, as well as raise some determining factors in the decision making process involved in the purchase. It seeks to better understand the "packing factor", what is the perception about it, relevant design features and whether or not there is a significant influence between the judgment about that element and the purchase. The relevance of the cost factor at the time of choice is easily perceived in a number of industries or services, including pharmaceuticals. This is not to be ignored, but a packaging-focused approach, its influence on consumer judgment and a possible differentiation for technically similar products is proposed here.

From the diffusion of generic drugs, the questioning by the consumer of issues related to the choice between different drugs, whether "branded" or generic, whether generic or similar, has recurred. Sometimes factors 
related to the price variation are not considered, as in the program "Aqui Tem Farmácia Popular" (Here's Popular Pharmacy), which proposes to subsidize the price of some drugs for hypertension, diabetes and contraceptives by the Brazilian Federal Government, resulting in the gratuity for users. Situations like this demonstrate the importance of delineating all the factors that lead to a given choice. A Resolution issued by the Board of Directors of the National Agency of Sanitary Surveillance (ANVISA) - RDC No. 71, of December 22, 2009 (Brasil, 2009), define rules and criteria for drugs labeling and packaging. The resolution brings the definitions of primary packaging (which maintains direct contact with the medicine) and secondary (packaging that is in contact with the primary packaging and which may constitute wrap or any other form of removable or non-removable protection). The present work proposes to study exclusively the secondary packaging, taking into account that these are in direct contact with the consumer at the time of purchase. As for the specific part in which the packaging of generic drugs is treated, the great particularity is related to the obligation and form of placement of a yellow stripe that easily identifies this class of drugs, besides defining technical aspects related to the presentation of the same.

\section{Generic drugs}

Several studies, such as Ramalho (2006) and Viana (2002) attempted the impact of the introduction of generic drugs in Brazil, outline scenarios where its use is inserted and analyze the perception of society about the segment. Other authors, such as Farina (2009), Jordão (2000), Sun (2004), Fronteli (2009) and Lyra (2004) did not focus his studies specifically on generic drugs, but marketing issues and consumer behavior, demonstrating the relevance of the issues related to the theme for the sector analyzed.

Among the studies in the literature, we highlight Yokoshiro (2009) who studied the relationship of influence between the brand and organizational image, the perceived risk and the intention of prescribing generic drugs. When conducting the research with doctors from Salvador (Bahia), the author points out that there is a relationship between these three factors. One of its main conclusions is related to the fact that the value of the organizational brand can be a strategic alternative in reducing the perception of risk in the market of generic drugs and, thus, a competitive differential. Nishijima (2003) studied the economic impacts caused by the insertion of generic drugs, without dismembering the focus established in the price of the original drug. From the econometric models used by the author, the establishment of three main conclusions was possible: (1) the prices of branded drugs that have become generic reference, were reduced when they began to face competition from generic; (2) the branded drugs with the largest share of market revenue were the ones that attracted the most generics; and (3) branded products that faced competition from generics showed price elasticity and demand higher than those who did not come to face them.

Regarding international experiences, Vallès et al. (2003), Königbauer (2007), Regan (2008), Gonzalez et al. (2008) and Hellerstein (1998) have also studied issues related to generic drugs at specific sites. In this sense, we highlight Lexchin (2004) who, in detailing the specific situation of Canada, focused on issues related to the development of generic drugs and their impact on competition with reference drugs. Kobayashi et al. (2011), when conducting a survey-type research, proposed to understand the generic drug market in Japan with the main purpose of capturing the perception and acceptance in that population context. Likewise, Geitona et al. (2006) also studied issues related to generics and consumers in Greece.

\section{Research method}

This study was structured in four main parts. Firstly, a literature review, addressing issues such as acceptance and clarification of the population, consumer behavior, economic impacts, market aspects, regulatory legislation and evolution of the concept, as well as studies that involved not only generic drugs but also general medicines. No studies specifically focused on the packaging of generic drugs and their impact on consumer behavior were found, although Bertoldi et al. (2005) have studied the issue of generic drug packaging and its recognition by the consumer. A review was also carried out related to aspects of Marketing Administration, specifically focusing on Consumer Behavior, with the purpose of explaining all the complexity hidden in the act of purchase.

In the second stage of the study, two focus groups were held to capture impressions, feelings and understandings about various presentations of the same generic drug. Thus, the first focus group formed had heterogeneous characteristics, where the participants presented comments that they considered relevant, serving as the basis for the creation of a script that would guide the discussion in a more appropriate way. Among the aspects presented were gender, age group, training and level of knowledge about generic drugs. On the other hand, the second focus group had more homogeneous characteristics, such as previous experience with medications, age, use of continuous drugs and generic knowledge.

The third step was the formulation and application of a questionnaire in a small city located in the state of Minas Gerais, Brazil. The results of the focus groups were used as a basis for the questionnaire refinement, as well as information from direct observations with 
the consumers of generic drugs, carried out in a local pharmacy, specifically aiming the collection of elements to elaborate the study. The questionnaire was divided into four blocks, forming a total of 44 questions: Personal Information (questions 1 to 12); General aspects of drugs (13 to 27); Perception of packaging (28 to 40 ) and Scenario evaluation (41 to 44 ).

Finally, the fourth and last step was the treatment and analysis of the data obtained that served as the basis for the conclusions of the study, from the application of spreadsheet.

The survey was conduced in the city of Cana Verde, Minas Gerais, Brazil. The city is located in the south of the state, $212 \mathrm{~km}$ from Belo Horizonte and $940 \mathrm{~km}$ from Brasilia. According to the Brazilian Institute of Geography and Statistics (IBGE, 2012), the population of the municipality in 2010 was 5,589 inhabitants and GDP per capita was R $\$ 6,379.27$ in 2008 (as an element of comparison, GDP per capita of Minas Gerais State was R \$ 14,233.00 in the same year). The city has three public health establishments and 92 business establishments, including three drugstores. The municipality is marked by great agricultural activity, emphasizing essentially the coffee cultivation and the creation of dairy cattle. Still according to IBGE, the population of the state of Minas Gerais was 19,597,330 inhabitants in 2010, distributed among 853 municipalities. The same source indicates that 6,256,069 inhabitants live in 716 small cities of the state with up to 25,000 inhabitants. This study considers Cana Verde as representative of the small cities of the state of Minas Gerais (32\% of the population of the state), as well as other regions of Brazilian countryside. The choice of a small city seems interesting as a field of research, since its reality may be different from that observed in large metropolitan centers, but it represents a considerable part of the population of the state and of the country.

\subsection{Sampling}

According to Triola (1999), any type of surveys or studies in a whole population (census) is in general quite complex, considering several factors, among which the limits of cost and time stand out. Thus, a smaller portion of the sample population is routinely employed, which can be understood as a portion of the study population, which has the same characteristics and allows a limited generalization of the results found. According to the author, any sampling process is error-prone, but these can be minimized by applying appropriate techniques, such as establishing results with error estimates and confidence intervals. Another point highlighted is that the best method to choose a sample is random selection, in which every member of the population has the same chance of being chosen. To calculate the sample size that yields statistically significant results, the following Formula 1 was used (Babbie, 1990):

$$
n=N \cdot z \frac{N \cdot z^{2} \cdot P(1-P)}{N \cdot d^{2}+z^{2} \cdot P(1-P)}
$$

at where: $\mathrm{n}=$ sample size; $\mathrm{N}=$ size of study population; $\mathrm{d}=$ maximum error attributed; $\mathrm{z}=$ normal table value linked to the desired confidence level; $\mathrm{P}=$ proportion of positive responses.

With a greater prior knowledge about the population and a possible judgment about the proportion of positive responses, a greater value could be used for $\mathrm{P}(\mathrm{P}=0.80$, for example), which would bring a smaller sample. In the present case, since we did not have any idea of the answers direction, we chose to maximize the sample size, assigning a value of $\mathrm{P}=0.50$. Due to technical and time constraints, a sample of 42 people was chosen, corresponding to a $15 \%$ error with a $95 \%$ confidence or a $10 \%$ error with a confidence of $80 \%$. It is worth mentioning that, as Figueiredo \& Romeiro (2011) point out, a sample with a lower number than the one found does not detract from the results, but points to a lower degree of confidence and precision. In order to compare results between two different realities, the sample was divided into two subgroups of 21 people each: a group of non-users of any type of medication and another group consisting of people who used drugs.

\subsection{Questionnaires preparation}

There were 19 generic and 13 similar presentations for the drug under study, being used in the research eight products available in the regional market studied (Figure 1), being seven generic and one similar. The drugs had the names of their respective laboratories camouflaged and were numbered from one to eight. The option to study with this determined number of laboratories was to balance two points: inconclusive results due to few labels being studied and possible confusion caused by too much visual information resulting from the exposure of many packages. Only a similar drug was used, because, although this was not the focus, an attempt was made to analyze the relationship between this class and generics.

The application took the form of an interview to facilitate the access of older people and ensure the minimization of possible discrepancies due to lack of understanding of what was requested, besides making the process less laborious for the interviewee. The beginning of each interview took place without the visualization of the drugs, with exposure only starting from question number 24 . The drug chosen for analysis was the same both during focus groups and questionnaires application. Captopril $25 \mathrm{mg}$ 


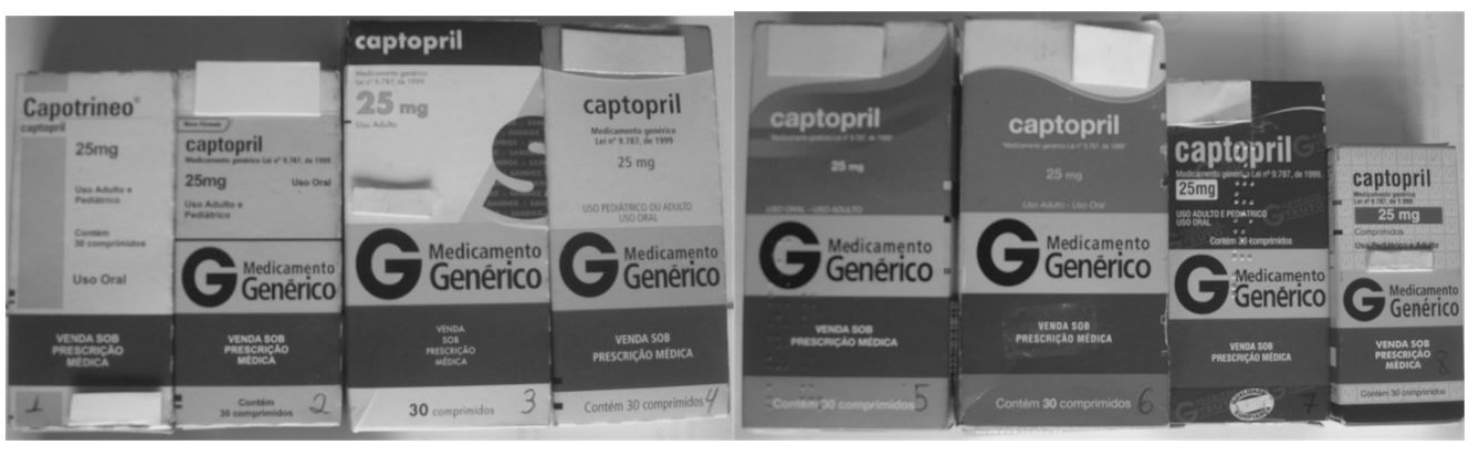

Figure 1. Labels used in the study. From left to right: Medications numbers 1 to 8 .

tablet with 30 tablets was used to treat hypertension. The reasons for choosing the drug are listed below:

- Belonging to a class of medications (anti-hypertensive drugs) that is widely used and highly representative for the entire population;

- Be one of the most used titles among anti-hypertensive drugs. In a survey in the city where the research was conducted, it was found that about $30 \%$ of those who use anti-hypertensive drugs use the study drug;

- Being part of the program "Aqui Tem Farmácia Popular", which leads to its gratuitousness and provides a greater wealth of analysis;

- Have several labels, among generic and similar, manufactured by different laboratories;

- Have generics established for several years in the market.

\section{Results and discussion}

\subsection{Knowledge about generic and similar drugs}

The survey verified that $60 \%$ of respondents stated that they had "good knowledge" about what generic drugs are and their results when compared to reference drugs, while 19\% said they knew "more or less" and 21\% "did not know". However, there is a total lack of knowledge about technical issues related to bioequivalence tests, and most of them do not know the reasons why there is a reduction in price, being erroneously cited as factors such as the use of cheaper raw materials. Adequate responses would be considered as the great need for investments in the development of the pioneer drug and the value of the brand explored during the exclusivity guaranteed by the patent protection. Correct answers were those that demonstrated knowledge about chemical constitution, efficacy and price. As for similar drugs, they are still significantly unknown and many still believe there is no difference between them and generic drugs: $86 \%$ of respondents reported knowing more or less what similar drugs are, while 7\% said they "know" and $7 \%$ "not knowing". Contrasting the two groups, it was verified that the knowledge between those who habitually use medicines and those who do not use were quite similar.

\subsection{Declared importance degree}

The importance that respondents stated was given to four characteristics related to packaging that were most prominent during focus groups. The order of importance both in the analysis of the results of the total sample and of the two subgroups separately was: "giving the feeling of trust and respect" (considered weight 7.83 on a scale of 0 to 10 ), "ease of remembering the laboratory" (Weight 7), "finding concern about customer satisfaction" (weight 6.14) and "beauty of packaging" (weight 2.83). This was considered the most complex part of the questionnaire, since many interviewees had difficulties in understanding the real meaning of each characteristic and the importance they assigned. Although the characteristics of "transfer the sensation of trust and respect" and "ease to laboratory remembering" may be complementary to each other, that is, the degree of confidence attributed by the interviewee may be related to the manufacturer of the drug, it was considered appropriate to treat. These aspects were considered separately, including the analysis of the results of the group not using users of constant use drugs, which showed less knowledge about brands and laboratories. Some had particular difficulty in abstracting from content (considered equal in formulation and results) and analyzing only the packaging. In the research pilot, it was tried not to interfere in the understanding, but since the great part presented difficulties in being able to understand what was being asked, it was established that in the research the concepts and the desired understandings were explained in the research. 


\subsection{Relationships when occurs gratuitousness}

For each of the four characteristics of the package mentioned above, respondent was asked to indicate the three packages that he judged the best representatives of each criterion and in which order (questions 32 to 35 of the questionnaire). Thus, respondents were asked to indicate: the three most beautiful packages; the three who would be able to recall the laboratory more easily; the three that most conveyed confidence and respect; the three packages that most demonstrated a greater concern with customer satisfaction in its development. The number of times each packing option appeared as the first choice in each feature and the total number of times it was remembered (sum of the three options) is shown in Table 1. The data are also shown of the total number of times each package was quoted, when considering all four characteristics.

An assessment of similar scenario to that provided by the "Aqui Tem Farmácia Popular" program was carried out, with free drugs for client. The format of three sequenced choices was again used. The number of times each package was chosen for purchase, both in the first and in the sum of the three options, is shown in Table 2. It was possible to analyze the linear correlation between the number of times each package was chosen as the best representatives of the four characteristics (beauty, easy recall of the laboratory, confidence and respect and concern with customer satisfaction) and the number of times it was chosen for sale. In the analysis, the greater the correlation between the choices for a particular characteristic and the purchasing choices, the greater the influence that the judgment about this characteristic exerts in the choice of purchase. Table 3 (columns 1 to 3 ) shows the relationships between the sum of the choices for the characteristics and the purchases.

Based on the data presented, it can be seen that the characteristic that presented a stronger relation with the choice for purchase was the perception of "trust and respect". Such an understanding is found both in the total sample and in the two subgroups and repeats independently of whether only the first option or the three choices are analyzed. It was also found that the correlations of the non-drug users subgroup were more pronounced, which can be understood as an indicator that their purchasing choices are more influenced by the perceptions about the packages

Table 1. Sum of the times each package appeared as the first option (F.O.) and in the total of the three options, according to each sample group (complete sample, drug users and nonusers).

\begin{tabular}{|c|c|c|c|c|c|c|c|c|c|c|c|}
\hline & \multirow[t]{2}{*}{$\begin{array}{l}\text { Package } \\
\text { Number }\end{array}$} & \multicolumn{2}{|c|}{$\begin{array}{c}\text { Most Beautiful } \\
\text { Package (beauty) }\end{array}$} & \multicolumn{2}{|c|}{$\begin{array}{c}\text { Easy to } \\
\text { Laboratory } \\
\text { Remembering } \\
\end{array}$} & \multicolumn{2}{|c|}{$\begin{array}{l}\text { Trust and } \\
\text { Respect }\end{array}$} & \multicolumn{2}{|c|}{$\begin{array}{l}\text { Finding concern } \\
\text { about Customer } \\
\text { Satisfaction }\end{array}$} & \multicolumn{2}{|c|}{$\begin{array}{c}\text { Total of Package } \\
\text { Citation }\end{array}$} \\
\hline & & F.O. & Total & F.O. & Total & F.O. & Total & F.O. & Total & F.O. & Total \\
\hline \multirow{8}{*}{ 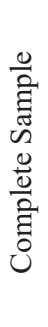 } & 1 & 1 & 2 & 2 & 5 & 2 & 9 & 2 & 8 & 7 & 28 \\
\hline & 2 & 1 & 3 & 2 & 6 & 3 & 7 & 2 & 5 & 8 & 20 \\
\hline & 3 & 4 & 7 & 5 & 16 & 4 & 15 & 6 & 18 & 19 & 73 \\
\hline & 4 & 8 & 12 & 7 & 27 & 7 & 23 & 4 & 18 & 26 & 85 \\
\hline & 5 & 12 & 17 & 9 & 38 & 11 & 25 & 11 & 25 & 43 & 106 \\
\hline & 6 & 10 & 16 & 8 & 34 & 6 & 17 & 4 & 16 & 28 & 84 \\
\hline & 7 & 5 & 12 & 7 & 24 & 5 & 13 & 8 & 19 & 25 & 59 \\
\hline & 8 & 0 & 8 & 1 & 9 & 1 & 7 & 3 & 9 & 5 & 23 \\
\hline \multirow{8}{*}{ 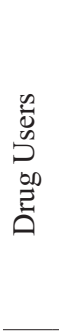 } & 1 & 0 & 0 & 1 & 2 & 1 & 4 & 2 & 4 & 4 & 10 \\
\hline & 2 & 1 & 3 & 2 & 4 & 2 & 5 & 2 & 3 & 7 & 15 \\
\hline & 3 & 2 & 12 & 3 & 10 & 3 & 8 & 3 & 10 & 11 & 40 \\
\hline & 4 & 4 & 11 & 4 & 9 & 3 & 10 & 2 & 8 & 13 & 38 \\
\hline & 5 & 5 & 16 & 3 & 12 & 5 & 11 & 5 & 11 & 18 & 50 \\
\hline & 6 & 7 & 12 & 4 & 14 & 3 & 9 & 2 & 8 & 16 & 43 \\
\hline & 7 & 1 & 6 & 2 & 6 & 1 & 5 & 3 & 9 & 7 & 26 \\
\hline & 8 & 0 & 0 & 1 & 1 & 1 & 4 & 0 & 2 & 2 & 7 \\
\hline \multirow{8}{*}{ 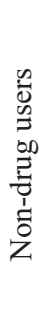 } & 1 & 1 & 5 & 1 & 4 & 1 & 5 & 0 & 4 & 3 & 18 \\
\hline & 2 & 0 & 1 & 0 & 0 & 1 & 2 & 0 & 2 & 1 & 5 \\
\hline & 3 & 2 & 10 & 2 & 8 & 1 & 7 & 3 & 8 & 8 & 33 \\
\hline & 4 & 4 & 12 & 3 & 12 & 4 & 13 & 2 & 10 & 13 & 47 \\
\hline & 5 & 7 & 15 & 6 & 13 & 6 & 14 & 6 & 14 & 25 & 56 \\
\hline & 6 & 3 & 12 & 4 & 13 & 3 & 8 & 2 & 8 & 12 & 41 \\
\hline & 7 & 4 & 6 & 5 & 9 & 4 & 8 & 5 & 10 & 18 & 33 \\
\hline & 8 & 0 & 2 & 0 & 4 & 0 & 3 & 3 & 7 & 3 & 16 \\
\hline
\end{tabular}


Table 2. Sum of times that each package was chosen for purchase as the first option and in the sum of the three options, whether or not gratuitous.

\begin{tabular}{|c|c|c|c|c|c|c|c|}
\hline \multirow{2}{*}{\multicolumn{2}{|c|}{ Package }} & \multicolumn{2}{|c|}{ Total Sample } & \multicolumn{2}{|c|}{ Drug Users } & \multicolumn{2}{|c|}{ Non-Drug Users } \\
\hline & & First & $\begin{array}{l}\text { Total of } \\
\text { Choices }\end{array}$ & First & $\begin{array}{l}\text { Total of } \\
\text { Choices }\end{array}$ & First & $\begin{array}{l}\text { Total of } \\
\text { Choices }\end{array}$ \\
\hline \multirow{8}{*}{ 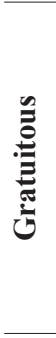 } & 1 & 1 & 10 & 0 & 5 & 1 & 5 \\
\hline & 2 & 5 & 17 & 4 & 9 & 1 & 8 \\
\hline & 3 & 3 & 7 & 3 & 5 & 0 & 2 \\
\hline & 4 & 13 & 27 & 5 & 13 & 8 & 14 \\
\hline & 5 & 6 & 17 & 3 & 7 & 3 & 10 \\
\hline & 6 & 2 & 14 & 1 & 7 & 1 & 7 \\
\hline & 7 & 8 & 22 & 2 & 10 & 6 & 12 \\
\hline & 8 & 4 & 10 & 3 & 5 & 1 & 5 \\
\hline \multirow{8}{*}{ 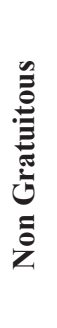 } & 1 & 18 & 23 & 9 & 11 & 9 & 12 \\
\hline & 2 & 1 & 28 & 1 & 14 & 0 & 14 \\
\hline & 3 & 3 & 4 & 3 & 3 & 0 & 1 \\
\hline & 4 & 6 & 13 & 3 & 6 & 3 & 7 \\
\hline & 5 & 4 & 13 & 2 & 7 & 2 & 6 \\
\hline & 6 & 1 & 6 & 0 & 3 & 1 & 3 \\
\hline & 7 & 6 & 32 & 2 & 16 & 4 & 16 \\
\hline & 8 & 3 & 5 & 1 & 1 & 2 & 4 \\
\hline
\end{tabular}

Table 3. Observed correlations.

\begin{tabular}{|c|c|c|c|c|c|c|c|c|c|c|}
\hline \multirow{3}{*}{ Characteristic } & \multicolumn{10}{|c|}{ Correlation } \\
\hline & \multicolumn{3}{|c|}{ Gratuitous } & \multicolumn{7}{|c|}{ Non gratuitous } \\
\hline & 1 & 2 & 3 & 4 & 5 & 6 & 7 & 8 & 9 & 10 \\
\hline Beauty & 0.26 & 0.23 & 0.29 & -0.28 & -0.42 & -0.43 & -0.30 & -0.02 & -0.50 & -0.12 \\
\hline Remembering Laboratory & 0.30 & 0.19 & 0.42 & -0.26 & -0.41 & -0.41 & -0.31 & -0.02 & -0.43 & -0.03 \\
\hline Trust an Respect & 0.48 & 0.32 & 0.60 & -0.23 & -0.30 & -0.29 & -0.38 & -0.01 & -0.23 & -0.10 \\
\hline Concerning about Customer Satisfaction & 0.33 & 0.21 & 0.45 & -0.21 & -0.24 & 0.04 & -0.06 & -0.21 & -0.32 & -0.13 \\
\hline Total of Choices & 0.34 & 0.24 & 0.45 & -0.27 & -0.37 & -0.34 & -0.28 & -0.07 & -0.40 & $*$ \\
\hline Price and First Option & $*$ & $*$ & $*$ & -0.39 & $*$ & -0.44 & $*$ & -0.32 & $*$ & $*$ \\
\hline Price and Total of Choices & $*$ & $*$ & $*$ & $*$ & -0.70 & $*$ & -0.78 & $*$ & -0.61 & $*$ \\
\hline
\end{tabular}

Between the sum of the choices for each characteristic and the sum of the choices of purchase, when gratuitousness occurs: 1. Considered the total sample; 2. Considered only drug users; 3. Considered only non-users. When no gratuity occurs: 4 . Among the first choices for each feature, the price and the first choice of purchase, when considered the total sample; 5 . Enter the sum of the choices for each characteristic, the price and the sum of the purchasing choices, when considered the total sample; 6 . Among the first choices for each characteristic, the price and the first choice of purchase when considered only the drug users; 7. Enter the sum of the choices for each characteristic, the price, and the sum of the purchasing choices when considering only drug users; 8 . Among the first choices for each characteristic, the price and the first choice of purchase, when considered only the non-drug users and does not occur gratuitously; 9. Enter the sum of the choices for each characteristic, the price and sum of the purchasing choices, when considered only the non-drug users and does not occur gratuitously; 10. Between the total of choices for each characteristic and the price of each label. *Correlation not existing or not evaluated.

than the choices made by the other subgroup. This is an interesting aspect because the group of non-users drugs, because this subgroup would be less influenced by a relationship between the graphic design of the packaging and the brand of the drug, ie the perception of trust and respect is in relation to packaging and not to the laboratory. It was also analyzed, a scenario in which there was no presence of the program "Aqui tem Farmácia Popular" and thus, consumers should pay for the chosen drugs their respective prices. The amount of times each package was chosen is shown in Table 2.
With this information, we can proceed in a similar way to the previous topic and calculate the correlations between the three choices for each characteristic and the new purchasing choices. The relationships between the price of each drug and the purchase also deserve to be analyzed. The results are shown in Table 3, columns 4 to 10 .

As can be seen in all scenarios, the highest correlation found is that between the price and the purchase choice. This, because it is a negative correlation, points out that the two sets of data move in opposite directions, that is, the lower the price, the greater the 
chance that it will be bought and vice versa. It was noted that in the group of non-drug users, this ratio is weaker than when compared to the group of drug users. This result complements the results found in the correlation analyzes when gratuitousness occurs. The analyzes of the previous scenario pointed out that non-drug users are more influenced by their perceptions about the packages.

The second scenario shows people who use drugs are more influenced by a lower price. For a better understanding of the negative signs existing in the correlations between the choices for the four characteristics raised (beauty, ease of remembering the laboratory, trust and respect and concern with customer satisfaction), the relationship between them and the price of each label as shown in Table 3, column 10. These data demonstrate that there is a very weak negative correlation between the choices for each characteristic and the price of the medicines, that is, the lower the price, the greater the number of times they should be remembered like more beautiful, more easily resemble the laboratory and so on.

This relationship was due to a particularity of packaging and at first sight does not seem to spell out a relationship that justifies a deeper analysis. It is noteworthy that the three choices for each characteristic were performed without price exposure, which excludes possible influences. Since the most representative relationship found negatively correlates the price and the possibility of purchase, the relations involving the perceptions of the packaging and the purchase choices play a secondary role, but by no means zero. Considering what has been stated, in this scenario one should not think of characteristics that more positively influence the choice, but in characteristics that least impact negatively. Thus, the less negative (closer to zero) is the correlation, the weaker is the negative impact caused by the characteristic, or otherwise, the stronger the positive impact on the purchase choice.

Analyzing the group of non-drug users, in which there was evidence of greater influence of the packaging, the results found show that the "trust and respect" characteristic is the one that has the least negative impact or which positively impacts the choice. In the subgroup composed of drug users, people who were more strongly influenced by price, the correlations found between the choices for the characteristics and the purchase choices were confusing and did not ratify the results obtained until then. It is considered that the results found in this group were distorted because of the strong relation between the price and the choice $(-0.78$ when the three choices were analyzed).

\subsection{Package preferences}

Some characteristics of the packaging design were also analyzed in an isolated way through dichotomous variables that portrayed two opposites present in the titles under study. As can be seen in Table 4, although there is some variation, preferences are recurrent in both the whole sample and the two subgroups.

Two points that stand out are related to the preference for a smaller package and for sayings located in the center. In the first case, the reasons explained during the interviews are related to a preoccupation with the waste and a greater convenience for drug transportation, handling and accommodation. Analyzing the placement of the words, it was recurrent that when located in the center the reading is facilitated. Between the opposites, "modern" and "traditional", the presence of curves in the packages, written in Braille and a greater wealth of details were pointed out as traces

Table 4. Design preferences.

\begin{tabular}{|c|c|c|c|c|}
\hline \multirow{5}{*}{ 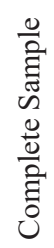 } & Smallest Package & $71.43 \%$ & $28.57 \%$ & Biggest Package \\
\hline & Stamped Package & $61.90 \%$ & $38.10 \%$ & Smooth Package \\
\hline & Live and strong colors & $59.52 \%$ & $40.48 \%$ & Kind and light colors \\
\hline & Centerized text & $92.86 \%$ & $7.14 \%$ & Text in the corners \\
\hline & Modern package & $65.85 \%$ & $34.15 \%$ & Traditional package \\
\hline \multirow{5}{*}{ 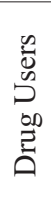 } & Smallest Package & $61.90 \%$ & $38.10 \%$ & Biggest Package \\
\hline & Stamped Package & $71.43 \%$ & $28.57 \%$ & Smooth Package \\
\hline & Live and strong colors & $61.90 \%$ & $38.10 \%$ & Kind and light colors \\
\hline & Centerized text & $100.00 \%$ & $0.00 \%$ & Text in the corners \\
\hline & Modern package & $70.00 \%$ & $30.00 \%$ & Traditional package \\
\hline \multirow{5}{*}{ 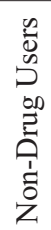 } & Smallest Package & $80.95 \%$ & $19.05 \%$ & Biggest Package \\
\hline & Stamped Package & $52.38 \%$ & $47.62 \%$ & Smooth Package \\
\hline & Live and strong colors & $57.14 \%$ & $42.86 \%$ & Kind and light colors \\
\hline & Centerized text & $85.71 \%$ & $14.29 \%$ & Text in the corners \\
\hline & Modern package & $61.90 \%$ & $38.10 \%$ & Traditional package \\
\hline
\end{tabular}


of modernity. Regarding the preferences for printed packages and bright and strong colors, although in the group of non-users of medicines the answers did not show a marked preference, in the complete sample the indices become more robust.

\section{Conclusions}

There was a considerable correlation between the judgments on packaging and the choice of purchase. Although this relation is not always homogeneous, moments in which there is no price variation provide a fertile field for the construction of a differential through this question. When the influence of price on purchase choices was also analyzed, this was shown to be the most significant, placing the aforementioned correlations in the background. It is worth mentioning that the price variation used in the study was higher than $40 \%$, an index that may have been able to induce more extreme purchase options. There appears to be a kind of "continuum", where the greater the price variation involved, the greater its influence, whereas the smaller the variation, the greater the relevance given to other aspects such as packaging, which makes packaging an important aspect in "Aqui tem Farmácia Popular" program.

Regarding the packaging characteristics, it was pointed out not only by the statement of importance, but mainly by the correlations made, that the most relevant aspect in a positive judgment and that is more strongly tied to the purchase choices is the "perception of trust and respect". The result was very consistent and replicated in the two subgroups analyzed. Another conclusion is related to the fact that non-drug users are more influenced by their judgment about packaging, whereas those who use drugs are more influenced by price.

Thus, packaging becomes even more important for "inbound" consumers and for drugs that are sporadically used, such as anti-inflammatories, analgesics and anti-fluids, which can be purchased by anyone. Although reasons that justify this understanding have not been addressed, it is believed that lack of experience and constant contact with the environment make people more susceptible to the effects of visual solutions developed for secondary packaging. Otherwise, those who already use medicines have a more homogeneous understanding of the equivalence of the various presentations in quality and effectiveness, making the graphic design of packaging less relevant and making the final price the basic criterion for choosing the product purchased.

Although aspects related to color are not the focus of this study, it is worth mentioning the prominence achieved by green packaging (packages 4 and 5), being the one that most pleased and / or attracted the attention of the interviewees. Design and ergonomics literature (such as Iida, 2005 and Pedrosa, 2002) often associates this color with positive ideas such as contact ability, tranquility, hope, well-being and health. That is, the sensations transmitted by the packages that most caught the attention of the interviewees are exactly those that meet the expected results of a drug, in addition to being deeply related to the characteristic pointed out as more important (trust and respect). Although this characteristic can be associated to a standard graphic design adopted by the laboratory and contributes to the user of the drug more easily remember the laboratory, this question ratifies the implicit influence that the packaging and its perception can exert on the consumers. It was also observed that certain preferences can be determined in relation to the packaging design, being very clear issues such as the taste for location of sayings in the centers and smaller packages. Other points such as the presence of prints, vivid and strong colors and the desire for a packaging that shows traces of modernity have also been verified.

This research aims to demonstrate how aspects related to packaging design, especially in its visual aspects, can positively influence the perception of consumers of generic drugs. As the example used in the research is a type of drug included in the "Aqui tem Farmácia Popular" program, the importance of the issue of price as a consumer choice could be reduced, bringing the possibility of valuation by the group analyzed of elements that go beyond purely economic criteria such as the perception of "trust and respect" elements related to the design of the packaging.

Another important aspect to be considered is the fact that the research was carried out in a small city, which turned out to be a peculiar condition for the survey, especially considering the ease of access to the interviewees. Interestingly, some aspects raised by the research, specifically the degree of knowledge about what is a generic medicine, corresponded to the study carried out in Japan by Kobayashi et al. (2011), which seems to demonstrate that the observed data may correspond to the situation of users of large Brazilian cities.

\section{Acknowledgements}

The authors would like to thanks FAPEMIG - Fundação de Amparo à Pesquisa do Estado de Minas Gerais (Research Support Fundation of Minas Gerais State) and CNPq - Conselho Nacional de Desenvolvimento Científico e Tecnológico (National Counsel of Technological and Scientific Development) for support this research project. We also would like to thanks the Brazilian taxpayers (especially of the basis of the economic pyramid) that funding the public and free Brazilian Universities. 


\section{References}

Babbie, E. (1990). Survey research methods. Belmont: Wadsworth.

Bertoldi, A. D., Barros, A. J. D., \& Hallal, P. C. (2005). Generic drugs in Brazil: known by many, used by few. Cadernos de Saúde Pública, 21(6), 1808-1815. http:// dx.doi.org/10.1590/S0102-311X2005000600029. PMid:16410866.

Brasil. (1999, 11 February). Lei $n^{\circ}$ 9.787, 10 de fevereiro de 1999. Dispõe sobre a vigilância sanitária, estabelece o medicamento genérico, dispõe sobre a utilização de nomes genéricos em produtos farmacêuticos e dá outras providências. Brasília, DF: Diário Oficial da República Federativa do Brasil.

Brasil. Ministério da Saúde. Agência Nacional de Vigilância Sanitária. (2009, 23 December). Resolução RDC $n^{\circ}$ 71, de 22 de dezembro de 2009. Estabelece regras para a rotulagem de medicamentos. Brasília, DF: Diário Oficial da República Federativa do Brasil.

Carvalho, M. C. R. D., Accioly, H., Jr., \& Raffin, F. N. (2006). Representações sociais do medicamento genérico por consumidores residentes em Natal, Rio Grande do Norte, Brasil. Cadernos de Saúde Pública, 22(3), 653-661. http://dx.doi.org/10.1590/S0102-311X2006000300020. PMid:16583109.

Evans, P. (1982). A Tríplice Aliança: as multinacionais, as estatais e o capital nacional no desenvolvimento dependente brasileiro. Rio de Janeiro: Zahar Editores.

Farina, M. C. (2009). O relacionamento entre as farmácias e drogarias e seu distribuidor: uma modelagem à luz da teoria do comprometimento-confiança do marketing de relacionamento (Tese de doutorado). Faculdade de Economia, Administração e Contabilidade, Universidade de São Paulo, São Paulo.

Figueiredo, A. C., \& Romeiro, E., Fo. (2011). As práticas de sistemas CAD e sua contribuição: um survey na indústria metal-mecânica mineira. Produção, 21(2), 344-354. http://dx.doi.org/10.1590/S0103-65132011005000024.

Fronteli, M. H. (2009). Comportamento do consumidor no varejo de farmácias e drogarias na mesorregião do norte pioneiro do Paraná (Dissertação de mestrado). Universidade Federal do Paraná, Curitiba.

Geitona, M., Zavras, D., Hatzikou, M., \& Kyriopoulos, J. (2006). Generics market in Greece: the pharmaceutical industry's beliefs. Health Policy, 79(1), 35-48. http://dx.doi. org/10.1016/j.healthpol.2005.11.004. PMid:16386326.

Gonzalez, J., Sismeiro, C., Dutta, S., \& Stern, P. (2008). Can branded drugs benefit from generic entry? The role of detailing and price in switching to non-bioequivalent molecules. International Journal of Research in Marketing, 25(4), 247-260. http://dx.doi.org/10.1016/j. ijresmar.2008.08.002.

Heineck, I., Gallina, S. M., Silva, T., Dal Pizzol, F., \& Schenkel, E. P. (1998). Análise da publicidade de medicamentos veiculada em emissoras de rádio do Rio Grande do Sul, Brasil. Cadernos de Saude Publica, 14(1), 193-198. http://dx.doi.org/10.1590/S0102311X1998000100028. PMid:9592225.

Hellerstein, J. K. (1998). The importance of the physician in the generic versus trade: name prescription decision. The Rand Journal of Economics, 29(1), 108-136. http:// dx.doi.org/10.2307/2555818. PMid:10182437.

Iida, I. (2005). Ergonomia: projeto e produção (2. ed.). São Paulo: Blücher.

Instituto Brasileiro de Geografia e Estatística - IBGE. (2012). Dados estatísticos de cidades brasileiras. Rio de Janeiro. Retrieved in 2014, May 10, from http:// www.ibge.gov.br/cidadesat/topwindow.htm?1

Jordão, J. A. O. (2000). Os direitos dos consumidores e as estratégias de marketing dos laboratórios farmacêuticos: o caso dos remédios falsificados (Dissertação de mestrado). Pontifícia Universidade Católica de São Paulo, São Paulo.

Kobayashi, E., Karigome, H., Sakurada, T., Satoh, N., \& Ueda, S. (2011). Patients attitudes towards generic drug substitution in Japan. Health Policy, 99(1), 6065. http://dx.doi.org/10.1016/j.healthpol.2010.07.006. PMid:20685003.

Königbauer, I. (2007). Advertising and generic market entry. Journal of Health Economics, 26(2), 286-305. http://dx.doi.org/10.1016/j.jhealeco.2006.08.008. PMid:17011648.

Lexchin, J. (2004). The effect of generic competition on the price of brand-name drugs. Health Policy, 68(1), 47-54. http://dx.doi.org/10.1016/j.healthpol.2003.07.007. PMid:15033552.

Lyra, A. M. F. (2004). Segmentação e comportamento do consumidor no mercado de farmácias e drogarias em Curitiba (Dissertação de mestrado). Universidade Federal do Paraná, Curitiba.

Miranda, C. A. S., Romeiro, E. (2008). Desenvolvimento de embalagens para produtos alimentícios típicos: um desafio metodológico. In Anais do XXVIII Encontro Nacional de Engenharia de Produção. Rio de Janeiro: ABEPRO.

Nishijima, M. (2003). Análise econômica dos medicamentos genéricos no Brasil (Tese de doutorado). Faculdade de Economia, Administração e Contabilidade, Universidade de São Paulo, São Paulo.

Nishijima, M., Biasoto, G., Jr., \& Lagroteria, E. (2014). A competição no mercado farmacêutico brasileiro após uma década de medicamentos genéricos: uma análise de rivalidade em um mercado regulado. Economia e Sociedade, 23(1), 155-186. http://dx.doi.org/10.1590/ S0104-06182014000100006.

Pedrosa, I. (2002). Da cor à cor inexistente (8. ed.). Rio de Janeiro: Editora UFF. 
Ramalho, W. (2006). Modelos de atitude em mercado de novos entrantes: uma análise com medicamentos genéricos, contribuições teóricas e validação nomológica (Tese de doutorado). Faculdade de Ciências Econômicas, Universidade Federal de Minas Gerais, Belo Horizonte.

Regan, T. L. (2008). Generic entry, price competition, and market segmentation in the prescription drug market. International Journal of Industrial Organization, 26(4), 930-948. http://dx.doi.org/10.1016/j.ijindorg.2007.08.004.

Santos, M. C. B. G., \& Pinho, M. (2012). Estratégias tecnológicas em transformação: um estudo da indústria farmacêutica brasileira. Gestão \& Produção, 19(2), 405-418. http://dx.doi.org/10.1590/S0104-530X2012000200013.

Sun, R. (2004). Análise do processo de decisão de compra de analgésico: um estudo exploratório com consumidores (Dissertação de mestrado). Universidade Presbiteriana Mackenzie, São Paulo.
Triola, M. F. (1999). Introdução à estatística (7. ed.). Rio de Janeiro: LTC.

Vallès, J., Barreiro, M., Cereza, G., Ferro, J. J., Martínez, M. J., Escribà, J. M., Iglesias, B., Cucurull, E., \& Barceló, E. (2003). A prospective multicenter study of the effect of patient education on acceptability of generic prescribing in general practice. Health Policy, 65(3), 269-275. http://dx.doi.org/10.1016/S01688510(03)00018-6. PMid:12941494.

Viana, L. J. P. (2002). A relação entre o medicamento genérico e o composto promocional do marketing farmacêutico (Dissertação de mestrado). Pontifícia Universidade Católica de São Paulo, São Paulo.

Yokoshiro, P. R. A. (2009). Doutor eu quero um medicamento genérico! Uma análise da influência das marcas organizacionais sobre o risco percebido na prescrição de medicamentos genéricos (Dissertação de mestrado). Universidade de Salvador, Salvador. 